Ewa EUKASZYK

University of Warsaw

ewaluk@al.uw.edu.pl

\title{
THE BRAZILIAN CASE: TOWARDS A PARADIGM OF TRANS-COLONIAL STUDIES
}

ABSTRACT The aim of this article is to discuss the limited applicability of the "standard" post-colonial method in the analysis of the Brazilian literature and culture. A new, trans-colonial paradigm is proposed instead, focusing on emerging idiosyncrasies rather than on the process of critical deconstruction of the European discourses and ideologies. In a comparative perspective confronting the studied case with other situations in the world, the article presents particular circumstances that shaped the trans-colonial pattern of development of the Brazilian culture. The factors and phenomena taken into the account are: the proportions of economic and cultural strength between the colony and its metropolis, the dynamics of the identity search that followed the moment of formal independence, the peculiarity related to the predominance of a non-printed (oral or handwritten) culture and finally the emergence of cultural distinctiveness alien to Eurocentric canons.

Keywords: Brazil, post-colonial studies, trans-colonial studies, cultural distinctiveness

Palabras clave: Brasil, estudios pos-coloniales, estudios trans-coloniales, distintivos culturales 
$\mathrm{T}$ he post-colonial studies undoubtedly became one of the cardinal paradigms of reflection in literary and cultural criticism during the last decades of the $20^{\text {th }}$ century, establishing a field of discussion on inter-cultural relationships that has been explored with an unprecedented intensity and assiduity. Nonetheless, the deepest idiosyncrasies of the non-European cultures are still to be explored. Quite a lot of misconceptions may still remain, due to the untranslatability of those cultures in terms of genres, ideologies or ways of cultivating scholarship formulated on the European ground and practised in the Western-oriented academic milieus. ${ }^{1}$ The post-colonial discourse still seems to take a share in the fate of the colonial one: it is marked by the intellectual predominance of the metropolitan perspective whose criteria and values are surreptitiously maintained. On the other hand, as any other intellectual paradigm, post-colonial theory is doomed to face, sooner or later, an unavoidable exhaustion. No wonder that the death of post-colonial studies has been announced repeatedly since nearly a decade, both by individual researchers and collectivities, such as the round-table with Sunil Agnani, Fernando Coronil, Gaurav Desai, Mamadou Diouf, Simon Gikandi, Susie Tharu and Jennifer Wenzel, reported in the influential PMLA in $2007 .^{2}$

Even if the vitality of the post-colonial studies may still be observed in spite of their announced end, ${ }^{3}$ these circumstances justify the urge to renovate or supplement the exhausted paradigm. As one of the possible ways of further development, the concept of trans-colonial is progressively taking shape. As it happens to any notion under construction, several overlapping meanings of the term have been proposed. ${ }^{4}$ For the purpose of the analysis of the Brazilian culture in this article, the trans-colonial may be defined as a term referring to the process of overcoming not only the colonial situation itself, but also its further consequences, not only such as the post-colonial fixation on settling the accounts with the ex-colonizer, but also such as the dependence on styles, fashions, sets of aesthetic criteria or other kinds of paradigmatic content produced in

1 It has been argued that the Eurocentric "Theory's Empire”, dictating and legitimizing the current ways of reading, interpretation and cultural criticism, may have remained as a subtle form of symbolic violence that has survived both the end of the colonialism and the post-colonial studies. Cf.: D. Patai, W.H. Corral (eds.), Theory's Empire. An Anthology of Dissent, New York 2005.

2 P. Yaeger, 'Editor's Column: The End of Postcolonial Theory? A Roundtable with Sunil Agnani, Fernando Coronil, Gaurav Desai, Mamadou Diouf, Simon Gikandi, Susie Tharu, and Jennifer Wenzel', PMLA, Vol. 122, No. 3 (2007), pp. 633-651, at <http://dx.doi.org/10.1632/pmla.2007.122.3.633>.

3 Some researchers are even inclined to believe that the repeated "obituaries" concerning the post-colonial theory are precisely a proof of its vitality, namely as a sign indicating that its discourse still causes intellectual disturbance. Cf.: R.J.C. Young, 'Postcolonial Remains', New Literary History, Vol. 43, No. 1 (2012), pp. 19-42, at <http://dx.doi.org/10.1353/nlh.2012.0009>.

4 The term "trans-colonial" may be used, among other meanings, to speak about the collaboration between the elites of ethnic and cultural groups inhabiting the same region, across the frontiers of the territories occupied by different colonial empires. Cf.: M.S. Dodson, B.A. Hatcher (eds.), Trans-colonial Modernities in South Asia, London 2012 (Routledge Studies in the Modern History of Asia, 74). A first approach to formulate a definition of trans-colonial process has also been given in: E. Łukaszyk, 'Modele interakcji kultur w kontekście globalnym. W poszukiwaniu paradygmatów poza studiami postkolonialnymi', Kultura - Historia - Globalizacja, No. 12 (2012), pp. 103-115. 
the metropolis. ${ }^{5}$ The trans-colonial process is oriented towards the emergence of an idiosyncratic way of development of a culture, no longer defined by its colonial past, which in the contemporary Brazilian consciousness may indeed appear as a distant and rather nebulous historical horizon.

Speaking, more than a decade ago, about "the directions and the dead ends" of the discipline, Benita Parry stressed first of all the role of the post-colonial studies in reshaping the "domestic" visions of the empires, i.e. the perceptions concerning the course and the consequences of the colonial projects, elaborated inside the European cultures. Undoubtedly, as the essayist states, one of the achievements of post-colonial studies has been to extend the understanding to the tangible and imaginary presence of empire within the quotidian existence of the imperial homeland. ${ }^{6}$ Arguably, this achievement might be considered as one of the "dead ends" and a possible hindrance for the future, if it prevents the Eurocentric scholar from taking into account the reverse perspective, i.e. the inner cultural dynamics of "non-imperial homelands". The predominance of post-colonial studies as a ready-made pattern of understanding non-European cultures may conceal other conceptual keys. Meanwhile, the fact of having once been a part of an empire and the post-colonial corollaries of this fact, may actually not be or cease to be determinant for the "quotidian existence" of many cultures which we might be inclined to treat spontaneously as "post-colonial".

My intuition suggests to me that there are rather few "true" post-colonial cultures in the world. I am inclined to believe that the classical post-colonial paradigm, associated to a particular kind of dialogue, often classified, after Ashcroft, Griffith and Tiffin,, as a process of "writing back" to a European cultural or intellectual centre, may partially fit India or Maghreb, ${ }^{8}$ but not necessarily Brazil nor Malaysia, even if the latter also suf-

5 Further features of the trans-colonial process, as I see it, are discernible in other cultural cases around the world. To give examples, the trans-colonial renegotiation may revisit identities and distinctions "masked" both by the colonial tendency to merge local identities together and the post-colonial policies of national unity; such is the case of Arab-Berber dualism in contemporary Morocco that becomes one of the major topics of trans-colonial renegotiation in the Maghreb. Quite opposite tendency may be observed in Malaysia, where the trans-colonial process of fragmentation into "small identities" appears as concurrent with the search for inclusion into larger horizons of a specifically conceptualized "Islamic civilization". Cf.: eadem, 'Semiofory pogranicza: od postkolonialnej emancypacji do transkolonialności (zapiski z Kuala Lumpur)', Kultura - Historia - Globalizacja, No. 14 (2013), pp. 165-177.

6 B. Parry, 'Directions and Dead Ends in Postcolonial Studies' in D.T. Goldberg, A. Quayson (eds.), Relocating Postcolonialism, Oxford 2002.

7 Cf.: B. Ashcroft, G. Griffiths, H. Tiffin (eds.), The Empire Writes Back. Theory and Practice in Post-colonial Literatures, London 1989.

8 Studying the dynamics of the literary development in such countries as Morocco and Tunisia, it is easy to discern the overlapping tendencies that partially coincide with the divergence between French-and Arab-speaking literature. Not all the produced writing is thus directed towards the ex-metropolis; the trans-colonial dynamics emerge also due to the fact that the settlement of accounts with the symbolic and physical violence perpetrated by the post-colonial national state becomes more important than the debate on the colonial past. Cf.: E. Eukaszyk, 'Is There Tunisian Literature? Emergent Writing and Fractal Proliferation of Minor Voices', Colloquia Humanistica, No. 2 (2013), pp. 79-93, at <http://dx. doi.org/10.11649/ch.2013.001>. 
fered a long-lasting colonisation. This intuition, evidently, must be verified in course of a thorough research in the future. In this article, I propose to cast a glimpse at the history of the Brazilian culture in order to sketch the external relationships it established over the last two centuries. But my hypothesis remains the same: the pattern of development of the Brazilian culture doesn't fit the post-colonial paradigm very well.

Not everything in the cultures that had suffered a colonization in the past turns automatically into post-colonial terms. Hypothetically, there must be, so to speak, a "non-postcolonial" pattern of development, in which the dialogue with the ex-colonial metropolis is not necessarily the crucial nor the dominant factor. Some ex-colonial cultures could have taken other roads, leading to their complete emancipation, realized, symbolically, through the attitude of "forgetting Europe". Does such a moment really come? In what sense? I am inclined to argue that the Brazilian culture reached such a stage; the task of tracing back the path leading to it is a fascinating intellectual challenge.

My main goal in this article is therefore to reflect upon the possibility and the necessity of introducing a new paradigm of reflection, situated either beyond or in parallel in relation to the post-colonial studies. The central aspect in the lime-light would be still the quest for cultural identity, autonomy and authenticity. Nevertheless, the focus of the trans-colonial approach should switch to ruptures and emerging idiosyncrasies, rather than concentrating on the process of taking position in relation to the European sources or cultural roots. The essence of the post-colonial, as I see it, resides in the continued dialogue with the ex-metropolis, conducted in the conceptual terms established through the cultural transmission that occurred under colonial conditions. But the emancipating culture may also perform what - after Heidegger and Vattimo might be called a Verwindung, healing the wounds inflicted by the colonization and finally turning towards new objectives and modalities of development that can no longer be inscribed in European or Eurocentric categorizations. In consequence, the general orientation of the trans-colonial studies ceases to be revisionist; what I believe should be developed in such an approach is rather a cognitive sensibility to ruptures, discontinuities and, on the other hand, the emerging patterns of culture, patterns that cannot be reduced neither to followings of some European precedents, nor to reaction against Europe and the European values imposed through the colonization.

For many reasons I shall present below, the Brazilian culture escapes the post-colonial approach. It can be better understood if we use a modified set of intellectual tools, rather than the "standard" post-colonial type of analysis. The Brazilian case is certainly worth studying for its own sake and for its own peculiarity, yet at the same time it fascinates as an example of a "complete cycle" of cultural emancipation. It permits to deduce some premises for the study of the trans-colonial cultural dynamics that may be observed in less advanced stage in other parts of the world. Roughly by the end of the $20^{\text {th }}$ century, as I see it, Brazil reached the full stage of cultural independence, by which I understand the appearance of an idiosyncratic cultural system, based on a particular set of values, traditions and paradigms, irreducible to external parallelisms, similarities or sources. It has not only won its recognition as a part of the global cultural system, but also started to organize its own network of global relationships, for instance through 
the recent idea of the "Atlantic convergence" ("convergência atlântica"), opposed to the post-colonial project of the Lusophony launched by Portugal in the 90.ties.

Before we reach these recent ideas, the question that should be asked in the first place is how and why this "complete cycle" originated. Diverse historical and cultural circumstances leading to a "non-postcolonial" shaping of Brazil should be taken into account. I think its emergence had been made possible by a series of particular circumstances, such as the proportions of economic and symbolical strength between the colony and its metropolis. After the formal, political independence, a peculiar phenomenon of the search for a "stronger metropolis" took place; finally the hybridity of the emerging cultural system had to be creatively interpreted. Thus, I'm going to discuss such aspects as the importance of the chronological location of the political independence (conjugated with the rhythms of development shaping the metropolitan culture), the particular dynamics of identity search that followed the moment of formal independence, and finally the affirmation of cultural distinctiveness and peculiarity.

\section{THE IMPORTANCE OF "WHEN"}

The notion of post-colonialism seems to reveal extreme elasticity. Since its appearance in the 1960ties, this paradigm has been applied to ever increasing number of situations, located in different geographical and chronological contexts. Ewa Thompson, for example, used the post-colonial pattern of reflection to analyse the relationships between Russia and its "subdued margins", going as far as reading in post-colonial terms some of the history of Central Europe during the $19^{\text {th }}$ century. ${ }^{9}$ Nevertheless, I would rather object to this approach, considering that the peculiarity of post-colonial situation as a specific phenomenon among other forms of inter-cultural relationship consists in a particular quality of the dialogue that it provokes, classified by Ashcroft, Griffith and Tiffin as "writing back". If this particular type of dialogue is to take shape, a basic condition must be fulfilled: the dominant culture should attain a certain level of receptivity or interest in the dominated culture. Such an interest, essentially alien to the $19^{\text {th }}$ century's mentalities, ${ }^{10}$ became present, either in pronounced or in merely incipient forms, in all the Western colonial metropolises during the $20^{\text {th }}$ century. The emerging voices of the colonized could meet with a relatively favourable response due to the inner rhythm of development of the Western-European culture, which, due to the bursting of the $20^{\text {th }}$

Cf.: E. Thompson, Imperial Knowledge. Russian Literature and Colonialism, Westport 2000 (Contributions to the Study of World Literature, 99).

10 Even if several elements of the Romantic culture might incline the Western man to get some interest in the picturesque aspects of non-European cultures, the typical product of the $19^{\text {th }}$ century literature is an idealistic, fictionalized approach to the native reality, illustrated in Brazil by the novels by José Alencar. The appearance of the first non-European voices on the literary scene, such as a descendant of the African slaves, João da Cruz e Sousa, certainly marks the end of the $19^{\text {th }}$ century, nonetheless it is significant that these early figures adopt quite faithfully the literary paradigms of European origin, such as symbolism, instead of modifying or critically deconstructing them. 
century's modern cultural revolutions, entered a "receptive stage" and started to search for external sources of inspiration. This condition was prepared, among other factors, by the avant-garde artistic movements: cubists, for example, gave importance to the African sculpture. Later on, in France, the question of Algeria was placed in the centre of attention by the great intellectual figures of the time, such as Sartre and Camus. In Great Britain, some genuine interest in African literature arose and some authors started to be published as early as the 1950s. ${ }^{11}$ The same dynamics can be observed also in a "minor" colonial metropolis such as Lisbon, where a manifold literature speaking about Africa and different signs of interest concerning African ways of life can be observed since the 1950s (even if the independence of the Portuguese "overseas provinces" came as late as 1975). Therefore, the roots of post-colonialism as an intellectual movement are evidently older than the formal decolonisation, and the phenomenon can be understood in terms of an "Encounter" (in the meaning proposed by Jan Kieniewicz, as opposed to a mere "Contact"). ${ }^{12}$ The post-colonial dialogue had been prepared by the evolution of viewpoints that started already during the anterior, colonial period. This dimension of readiness has a crucial importance.

At the same time, this dimension of previous preparation is missing both in the Brazilian and the Russian $19^{\text {th }}$ century's case, studied by Ewa Thompson. As it seems, Russian culture didn't open to any kind of post-colonial dialogue. Concerning Polish history, I agree that the dependence from Russia during the $19^{\text {th }}$ century might be seen in colonial terms, but I don't see any sign of a post-colonial "writing back" to Moscow in the Polish culture ever since. There had been a colonial, perhaps, but not a post-colonial experience. Similarly, I believe that Brazil had a colonial, but not a post-colonial experience, and hardly any sign of "writing back" to Lisbon can be observed. If any cases of such phenomenon of "writing back" are to be cited, they don't possess the vital dynamism that characterizes the post-colonial debates in other parts of the world.

In my opinion, first circumstance that contributed to this "silent divorce" between Portugal and Brazil might be the lack of receptivity in the dominant culture, due quite simply to the date of the Brazilian independence, which occurred as early as 1822 . Too early for the kind of self-critical reflection and openness as a state of mind that should occur in the metropolitan elites. At the beginning of the $19^{\text {th }}$ century, Brazilian problems and concerns were hardly mentioned in the metropolitan cultural discourse. The difference is considerable, if compared to what happened more than a century later in relation to the African decolonization. The level of self-critical consciousness of the

11 To give an example, the case of the Nigerian Yoruba writer Amos Tutuola became paradigmatic. His first full-length, internationally recognized novella, The Palm-Wine Drinkard, was published in London in 1952 . This fact precedes by nearly a decade the decolonization of the former Colony and Protectorate of Nigeria, finalized in 1960-1961.

12 Cf.: J. Kieniewicz, 'Cristãos e especiaria: The Portuguese Impact on the Malabar Christian Community' in P. Malekandathil, J. Mohammed (eds.), The Portuguese, Indian Ocean and European Bridgeheads 1500-1800. Festschrift in Honour of Prof. K.S. Mathew, Tellicherry 2001, s. 119-132 (Institute for Research in Social Sciences and Humanities of MESHAR, 2). The notions of Contact and Encounter are also to be found in many other texts by this author. 
Portuguese intellectual elites, even if still blind to many truths, was nevertheless quite different, characterized at least by an incipient interest in African matters and a lot of either hidden or revealed sympathies for the colonized. This intricate network of both positive and negative affects has given rise to a complex post-colonial interaction (this time in the full and proper meaning of the term "post-colonial") between Lisbon and its former African dependencies that can still be observed today.

Portugal and Brazil got separate without activating the same kind of "post-dialogue". Brazil could seem quite neutral from the Portuguese point of view. Even if the "Brazilian adventure" constituted such an important part of the Portuguese historical experience, it is possible to claim that this part of the past is no longer a matter of discursive re-elaboration. It's something that doesn't "hurt" in the Portuguese conscience, especially if compared to the African case. Brazil has formally been present in the official discourse of Lusophony (understood as a "community of language and historical destiny") promoted by Lisbon since the emergence of this concept in the 70.ties, but there has been no specific "Brazilian question" in it. ${ }^{13}$ It doesn't pose any problem to the Portuguese consciousness. And vice-versa. The deconstruction of the Lusophone project has been recently operated by a group of Afro-Brazilian researchers. ${ }^{14}$ The authors contributing for the volume of Afro-Rizomas propose the notion of the "Atlantic convergence" ("convergência atlântica") as a counter-proposal in relation to the euphemistic Lusophone definition of a "community speaking a common language" that simply corresponds to the historical reality of peoples colonized by the Portuguese. The notion of the "Atlantic convergence" implies an autonomous affirmation of a non-Western, non-Eurocentric, non-Lusocentric canon originating from the African values and ways of conceptualizing the reality. Yet the main objective of "Atlantic convergence" is neither the deconstruction of the Lusophone project nor the attack directed against the post-colonial ideology promoted by the ex-metropolis, but rather more pacifically, the establishment and exploration of bonds connecting Brazil with its own African roots.

\section{THE CENTRE AND THE PERIPHERY}

At the beginning of the $19^{\text {th }}$ century, the balance between the colony and the metropolis was quite different if compared to what happened, more than a century later, in the African case. First of all, Portugal at that moment was indeed a very weak metropo-

13 The idea of collaboration with Brazil was strongly present in the incipient Lusophony in the 70s, in parallel with the idea of collaboration with Galicia (based on common origins in the Medieval Galaico-Portuguese language); yet this original concept had relatively little impact either in Portugal or in Brazil. The greatest cultural and political investment in the Lusophony happens in the 90.ties and is clearly related to the post-colonial - or even, according to some critical voices, neo-colonial dimension of the Portuguese presence in Africa. Cf.: A. Margarido, A Lusofonia e os Lusófonos. Novos mitos portugueses, Lisboa 2000 (Africanologia).

14 Among other publications, cf.: J.H. de Freitas Santos, R. Riso (ed.), Afro-Rizomas na Diáspora Negra. As literaturas africanas na encruzilhada brasileira, Rio de Janeiro 2013. 
lis. In economic terms, it would not be exaggerated to speak rather of the Portuguese dependence on Brazil, than of the Brazilian dependence on Portugal. This atypical "strength pattern" can also be observed in the cultural and the ideological domain. The colony started early to lead its own cultural life, even if incipient in comparison to the European standards. But the Portuguese standards of the time were also far from the European ones; it means that as early as in the $17^{\text {th }}$ century Brazil could be culturally and ideologically attractive in the eyes of many a gifted or adventurous individual, such as an explorer or an enthusiastic Jesuit priest. In other words, the colony tended to absorb the talents from the metropolis, not vice-versa.

The nature of the Portuguese colonial discourse, at the pre-modern stage of its formation, was such that it could be easily converted to serve the Brazilian cause as well. The legitimization of the Portuguese dominion was largely due to the eschatological vision of the "Fifth Empire", whose chief producer was the Jesuit priest António Vieira, active, for an extensive part of his life, in the Brazilian province of Maranhão rather than in Lisbon. The discursive tradition established both by his preaching and some of his "prophetic" writings, copied manually during the $17^{\text {th }}$ and $18^{\text {th }}$ centuries, created deep roots in the colony. In general terms, it can be claimed that the whole mythical system of the Portuguese culture, with such crucial elements as the belief in the mystic return of the "hidden king” D. Sebastião, that would bring justice and prosperity to the society as a whole, was, already at an early date, fully assimilated and transformed on the colonial ground. Brazil got its own D. Sebastião's island, Ilha dos Lençóis, situated near the coast of Maranhão. The Portuguese national myth started to be associated, in Brazilian imagination, with the peculiar population of that island, characterized by unusually high percentage of albino individuals. At the basic level of popular imagination, the idealistic vision of future fulfilment ceased to be related to anything that would come from the metropolis.

The relation between the centre and the periphery became thence deeply ambivalent. It could be argued that Brazil constituted the dominating part of the colonial system, both economically and symbolically, which was reflected in the political process of its emancipation (an ambitious ruler preferred the colony to the metropolis and sacrificed the latter to establish himself in the former). Nevertheless, there are more ambivalences than just these. In the cultural domain, Brazil could profit of its own weaknesses in a surprising way. The instances of control in the colony were feeble; this fact introduced a margin of freedom for the thought that didn't exist in the stifling atmosphere of the metropolis, dominated by the Inquisition and other instances of repression. The lack or insufficiency of print and the predominance of a peculiar oral-handwritten culture paradoxically meant the absence of censorship, impediment that slowed down the circulation of ideas in Portugal.

The oral-handwritten culture that I just mentioned could also reveal its surprising value for the emergence of the idiosyncratic Brazilian patterns. Seemingly so anachronistic and so limited in its extent, this culture of the handwritten "private word" could be particularly meaningful as a space of freedom, contrasting with the sphere of the printed "public word", subdued to the official control. In fact, even at a very posterior date, some intent to rebuild this culture of the "private word" reappeared, as opposed to 
the officially controlled cultural system. In the $20^{\text {th }}$ century, the history of Brazilian poetry would be blatantly incomplete if we neglect such phenomena as the "generation of the mimeograph" ("geração do mimeógrafo"), emerging at the beginning of the 1970s, producing a peculiar figure of a poet selling his or her work in the streets, in form of mimeographed leaflets. This creative attitude gave continuity to the tradition of popular and semi-popular "cordel literature" ("literatura de cordel"), ${ }^{15}$ parallel to the erudite patterns of culture and as important as an idiosyncratic phenomenon of "Brazilianness". These seemingly "lower" or "marginal" forms of writing and putting the written word into circulation show their crucial importance if we change the perspective and start to search for the sources of a genuinely Brazilian cultural idiom. ${ }^{16}$

\section{IN SEARCH OF A “STRONGER METROPOLIS"}

The discursive power of the metropolis could be felt as very feeble in comparison to those spontaneous bursts of creative imagination. In fact, in the $18^{\text {th }}$ or at the beginning of the $19^{\text {th }}$ century, the metropolitan Lisbon was nothing more than a provincial European city and the literary Portuguese was nothing more than a minor European language. Paradoxically, there is a surprising "detour" in the Brazilian success story of cultural emancipation, detour that could be at least metaphorically labelled the search for a "stronger metropolis". This phenomenon can be explained in a simplified way as a search for a new European source of inspiration. In the second half of the $19^{\text {th }}$ century, Brazil, after being for several decades politically and culturally independent from Portugal, developed a peculiar kind of dependence in relation to France. In cultural terms, Paris started to play for the Brazilians almost the same role as the colonial metropolis usually does, imposing norms, models, fashions and discourses (obviously without incurring any risk of political dominance). These cultural paradigms were certainly not imposed through violence, coercion nor by political power of a new colonizer; nevertheless, they seem to be "masochistically" self-imposed by the Brazilians themselves. The fatal consequences of the excessive fondness for this enthusiastically chosen new metropolis became visible through the clash of Canudos, a minor event in concrete, palpable terms, but crucial as a symbolical case, revealing the incompatibility between the modes of thinking imported from Europe and the local cultural patterns.

Brazil became so fascinated with certain "ready-made" categories taken from the French culture, such as the republican ideal of state and the Cartesian way of thinking, that some genuine elements of its own cultural idiom, incarnated in the popular,

15 The denomination "cordel literature" refers to the fact that these cheap, popular prints illustrated with woodcuts and sold in the streets and fairs, were hung from strings in order to display them to the potential buyers.

16 On the other hand, as a complementary phenomenon, the "residual orality" should be also taken into account as a part of this specific cultural idiom. Cf.: M. Lajolo, 'The Role of Orality in the Seduction of the Brazilian Reader: A National Challenge for Brazilian Writers of Fiction', Poetics Today, Vol. 15, No. 4 (1994), pp. 553-567. 
communitarian vision that gave birth to the settlement of Canudos and in its charismatic, "apostolic" leader, António Conselheiro, turned literally incomprehensible for the social and intellectual elites. Canudos, with its peculiar religious ideal, became the synonym of ignorance and superstition in the eyes of the Brazil thinking in French, according to Cartesian paradigm. Finally, the inhabitants of the settlement were exterminated, and with them the misunderstood way of "Brazilianness" seemed to be eradicated, too. The "self-colonized" Brazil became blind to its own peculiarity and to some crucial parts of its own cultural essence.

The military intervention in Canudos may seem a step backward in the development of a genuinely Brazilian pattern of culture. But paradoxically, the phenomenon of choosing a "stronger metropolis" can be also interpreted as a step forward, towards the full cultural emancipation. Evidently, Paris as a "new metropolis" could not impose its values through a real dominance and oppression. It had been not only freely chosen as a new, attractive metropolis, but to a high degree constructed, "invented" by the Brazilians themselves, shaped according to their desires. Any apparently "hegemonic" discourse emanating from Paris, taken in depth, would reveal its true nature as a purely Brazilian (mis)conception.

\section{INTERPRETING THE HYBRIDS}

A similar phenomenon of "cultural masochism" can be observed if we consider the visions and interpretations of hybridity, dimension that seems so essential to the image the Brazilians could make of themselves. During the $19^{\text {th }}$ century, and shamefully also during a large part of the $20^{\text {th }}$ century, the ethnic diversity and so typically Brazilian presence of mestizos and mulattoes was often interpreted in terms of degradation. This concept was evidently an echo of some European ideas concerning race and racial purity. Patently, these ideas brought disastrous consequences in Europe; in Brazil they contributed to slow down the process of cultural emancipation. As long as the Brazilians regarded themselves as inferior to all other nations of the world for the sheer fact they were to a supreme degree the product of racial, ethnic and cultural miscegenation, the search for authentic identity was impaired. The decisive breakthrough in this path was done by Gilberto Freire. His much discussed theory of "lusotropicalism" put for the first time the miscegenation as a positively marked factor, opening a new way to conceptualize the Brazilian identity. Having penetrated the popular mentality, this new vision finally led to the proclamation of the Dia do Mestiço (Mixed Race Day), celebrated since 2005.

And again, as I see it, the concept of "lusotropicalism" was more a sign of rupture in relation to some general European misconceptions, still shamefully in vogue in many parts of Europe as Freire created his work, than properly speaking a form of dialogue with Portugal as an ex-metropolis. ${ }^{17}$ The new elaboration concerned basically the ab-

17 It is well known that Freire was celebrated by the Portuguese regime. Nonetheless, it is important to notice that this celebration came late, in the $50 \mathrm{~s}$, after a decade of exacerbated criticism. The Salazarist 
stract concepts of purity versus mixture (the latter started to be interpreted as a factor of development and enrichment, rather than negative and degrading sort of "spoiling"). It was one of the crucial steps towards the self-acceptance of the Brazilians, and this step was made rather autonomously than in conditions of dialogue or in the context of debate with the ex-metropolis.

My claim is that, since early in the $20^{\text {th }}$ century, we can speak of an important internal movement of self-interpretation, in which Europe played exclusively the role of a distant background and not that of a crucial partner. Even the adventure of the Brazilian modernism can be better understood as an idiosyncratic movement than as an importation of the models taken from the European avant-garde. And there is also something else. The Brazilian, and in a larger perspective the Latin American modernism, can be seen as the first literary movement that introduced important South-American contents to the transatlantic literary circulation. It established a precedent of something crucial: truly bidirectional cultural exchange. At this moment, the sources of literary novelty have been redistributed: inspiration ceased to be a unidirectional stream taking its source in Europe and inundating the extra-European, satellite cultures. Such a model is no longer true neither for literature nor for other domains of intellectual activity.

\section{AT THE GLOBAL MARKETPLACE}

The new conceptualization of the cultural and literary exchange between Europe and Brazil should be understood not in terms of "writing back" to the metropolis, but rather in terms of autonomous contribution to the global cultural market, such as it is implied in the vision of "world literature" proposed by David Damrosch. Returning in his book What Is World Literature ${ }^{218}$ to the concept of comparative literature - that could seem heavily overexploited or even anachronistic in the literary studies at the end of the $20^{\text {th }}$ century, but worth rethinking at the stage of depletion of the post-colonial criticism, Damrosch established a new conceptualization of the global literary reality. Planetary literature is not simply the sum of all literary works existing in the world, but a functional whole composed by the works put into circulation, translated or simply read both inside and outside their original context. In this vision, what emerges instead of an essential bipolarity of post-colonial dialogue is a new multilateral, planetary network of contacts.

Brazilian contributions to the global cultural circuits, even if they often gain international popularity, are nearly as often judged with severity by institutionalized criticism. Potentially, this could be explained by one of two reasons: a simple result of their dubious literary value or a sign of a misunderstanding resulting from discrepancies of cultural paradigms according to which such literary phenomena should be evaluated.

regime that at a given moment decided to exploit the Brazilian idea, was by no means the original receptor or promoter of the lusotropicalistic vision. 
Is it possible to talk about specific patterns of Brazilian culture, overlapping European standards? Is there any truly idiosyncratic conception of what a valuable literary work should look like? Are such idiomatic conceptions interacting in the global literary landscape? Would such writers as, just to take an example, Paulo Coelho, truly establish a new epoch? My intention is not to defend this particular writer more than any other (many better examples of emerging idiosyncrasies could be cited), but to call the attention to the necessity of admitting a plurality of canons and to the fact that some fundamental misunderstandings concerning cultural tastes, values and patterns of thinking are not to be excluded. Such a Brazilian cultural product as the Paz Guerreira. O Caminho das Dezesseis Pétalas by Talal Husseini ${ }^{19}$ may seem a nightmare of a reader formed in the Eurocentric literary taste, yet this book is clearly a result of that handwritten culture of prognostics, obscure conjectures and heterodox wanderings for some form of transcendent wisdom that I mentioned above as a source of the Brazilian idiosyncrasies. Even in the contemporary, post-modern context, where supposedly there is no canon, still there is a kind of "invisible paradigm" derived from a closed vision of sources of value in literature. How far this closed vision is to be identified with Eurocentrism, remains a point of discussion. But still the main aspect I would like to accentuate is something else. It's time to abandon the pattern of thinking about world literature in terms of a dialogue between the world and Europe, realized inescapably inside the forms and value frames that would remain understandable and acceptable from European perspective. The Brazilian literature, for sure, cannot be understood at its best in this optic. Why should it?

\section{CONCLUSIONS}

The main target, the main "objective" of Brazilian literature is self-interpretation. This process of reading and writing the identity happens not as a form of post-colonial "writing back" to Lisbon, Paris or Europe in general, but in conditions of full emancipation and maturity. Of course, it doesn't happen in isolation. There is still an important dimension of dialogue, but it is realized in pluralistic terms, as a multilateral dialogue with many participants, among which neither Portugal nor Europe are no longer the privileged partners. Africa and the search for a "southern transatlantic canon" may often appear as more important than Europe. Brazil may be much better understood in the context of a polycentric world. For this reason, a new, worldly context of studying it is a clear necessity.

The study of all those phenomena doesn't enter easily into the post-colonial paradigm, unless we redistribute its accents and displace its main scope to move the focus towards the problem of cultural autonomy, putting in the centre the discontinuity, the phenomena of rupture and, on the other hand, the emergence of idiosyncratic forms

19 T. Husseini, Paz Guerreira. O Caminho das Dezesseis Pétalas, Belo Horizonte 2011. The book, often compared to the epic vision of J.R.R. Tolkien, is at the same time a kind of manual of virtues that are to be acquired through initiation and quest. 
that slip completely outside the conceptual grade of Eurocentric cultural and literary terms. The post-colonial studies are typically centred on the problem of dialogue between the ex-colonized and the ex-colonizer, made possible by the emergence of a common language - in linguistic and also in conceptual and discursive terms. The birth of such a common language of concepts, ideas and discourses makes this dialogue viable and promotes the mutual understanding. Nevertheless, the negative side of this process is related to the danger of cultural uniformity, so often haunting the globalized world. But the monotonous landscape of uniform cultures is not as close at hand as it seems. Even in the globalized world, the cultures still tend to diversify, and this diversification should be taken as a primary topic of research. This is why the trans-colonial paradigm should look for the discrepancies and follow with all attention the emergence of idiolects whose discursive aims are located outside the post-colonial spheres of dialogue.

\section{BIBLIOGRAPHY}

Ashcroft B., Griffiths G., Tiffin H. (eds.), The Empire Writes Back. Theory and Practice in Post-colonial Literatures, London 1989.

Damrosch D., What Is World Literature?, Princeton 2003 (Translation/Transnation).

Dodson M.S., Hatcher B.A. (eds.), Trans-colonial Modernities in South Asia, London 2012 (Routledge Studies in the Modern History of Asia, 74).

Husseini T., Paz Guerreira. O Caminho das Dezesseis Pétalas, Belo Horizonte 2011.

Kieniewicz J., 'Cristãos e especiaria: The Portuguese Impact on the Malabar Christian Community' in P. Malekandathil, J. Mohammed (eds.), The Portuguese, Indian Ocean and European Bridgeheads 1500-1800. Festschrift in Honour of Prof. K.S. Mathew, Tellicherry 2001 (Institute for Research in Social Sciences and Humanities of MESHAR, 2).

Lajolo M., 'The Role of Orality in the Seduction of the Brazilian Reader: A National Challenge for Brazilian Writers of Fiction', Poetics Today, Vol. 15, No. 4 (1994).

Łukaszyk E., 'Modele interakcji kultur w kontekście globalnym. W poszukiwaniu paradygmatów poza studiami postkolonialnymi', Kultura - Historia - Globalizacja, No. 12 (2012).

Łukaszyk E., 'Semiofory pogranicza: od postkolonialnej emancypacji do transkolonialności (zapiski z Kuala Lumpur)', Kultura - Historia - Globalizacja, No. 14 (2013).

Łukaszyk E., 'Is There Tunisian Literature? Emergent Writing and Fractal Proliferation of Minor Voices', Colloquia Humanistica, No. 2 (2013), at <http://dx.doi.org/10.11649/ ch.2013.001>.

Margarido A., A lusofonia e os Lusófonos. Novos mitos portugueses, Lisboa 2000 (Africanologia).

Parry B., 'Directions and Dead Ends in Postcolonial Studies' in D.T. Goldberg, A. Quayson (eds.), Relocating Postcolonialism, Oxford 2002.

Patai D., Corral W.H. (eds.), Theory's Empire. An Anthology of Dissent, New York 2005.

Santos J.H. de Freitas, Riso R. (eds.), Afro-Rizomas na Diáspora Negra. As literaturas africanas na encruzilhada brasileira, Rio de Janeiro 2013.

Thompson E., Imperial Knowledge. Russian Literature and Colonialism, Westport 2000 (Contributions to the Study of World Literature, 99). 
Tutuola A., The Palm-Wine Drinkard and his Dead Palm-Wine Tapster in the Dead's Town, London 1952.

Yaeger P., 'Editor's Column: The End of Postcolonial Theory? A Roundtable with Sunil Agnani, Fernando Coronil, Gaurav Desai, Mamadou Diouf, Simon Gikandi, Susie Tharu, and Jennifer Wenzel', PMLA, Vol. 122, No. 3 (2007), at <http://dx.doi.org/10.1632/ pmla.2007.122.3.633>.

Young R.J.C., 'Postcolonial Remains', New Literary History, Vol. 43, No. 1 (2012), at <http:// dx.doi.org/10.1353/nlh.2012.0009>.

Dr hab. Ewa ŁUKASZYK, prof. UW (born in 1972) - professor at the interdisciplinary Faculty of "Artes Liberales", University of Warsaw. Author of several books on Portuguese and Lusophone literature, such as Wspótczesna proza portugalska ("Contemporary Portuguese Prose”, 2000), Terytorium a świat. Wyobrażeniowe konfiguracje przestrzeni w literaturze portugalskiej od schytku średniowiecza do wspótczesności ("The Territory and the World. Imaginary Configurations of Space in the Portuguese Literature from the End of the Middle Ages till the Contemporary Period", 2003) and a monograph on the novelistic work of José Saramago, Pokusa pustyni. Nomadyzm jako wyjście z kryzysu wspótczesności w pisarstwie José Saramago ("Temptation of the Desert. Nomadism as a Solution of the Contemporary Crisis in the Novelistic Works of José Saramago", 2005). Her research concerning the history of Brazilian literature resulted in the co-authorship of Historia literatur iberoamerykanskich ("History of Latin American Literature", 2010). 